\title{
Role of Potting Media in the Cultivation of Orchids - A Review
}

\author{
M. Sanghamitra*, J. Dilip Babu, B.V.K. Bhagavan and D.R. Salomi Suneetha \\ Department of Floriculture and Landscaping, College of Horticulture, Dr. YSR Horticultural \\ University, Venkataramannagudem, Tadepalligudem, \\ West Godavari district, Andhra Pradesh, India \\ *Corresponding author
}

\begin{tabular}{l} 
Key w or d s \\
$\begin{array}{l}\text { Orchids, Epiphytes, } \\
\text { Potting media }\end{array}$ \\
Article Info \\
\hline $\begin{array}{l}\text { Accepted: } \\
\text { 04 December } 2018 \\
\text { Available Online: } \\
\text { 10 January } 2019\end{array}$ \\
\hline
\end{tabular}

A B S T R A C T

One of the most important components of pot cultivation of flower crops is the choice of growing medium. It should be well aerated medium with good water retention capacity and good drainage. And ideal growing medium needs to be able to anchor the roots and stems so that the plant will not topple over as it grows larger, yet it should provide adequate moisture, nutrient and aeration to the plant. The cost, local availability and experience in substrate are usually the determining factors for choosing a particular substrate type. Orchids, being an Epiphytic in nature spread their roots over the branches of trees exposing them fully, therefore, the type of media used for growing epiphytic orchids should provide a surface over which the plants can cling to. A good mixture of media is useful in terms of all vegetative and flowering parameters. An ideal growing media should provide healthy environment for roots. It should be inert, porous and resistant to organic decomposition. It should be cheap and easily available (Bose and Bhattacharjee, 1980). The vigorous and healthy root system in epiphytic orchids was first step towards ensuring maximum growth. Hence selection of ideal rooting media provides a high degree of success for profuse root growth.

\section{Introduction}

Orchids are the most beautiful flowers in God's creation and have conquered the cut flower industry all over the world during the last few decades. Orchid cut flowers have emerged as leader in the international market and have immensely contributed to the economy of several developed and developing countries. They are valued for cut flower production and as potted plant in commercial floriculture owing to the wide range of colours, shapes, sizes and fragrance they display. Orchids are excellent for garden and can be grown in beds, pots, baskets, split hollows of bamboo pieces etc. They are marketed globally as cut flowers for making corsages, floral arrangements and boquets. They are also suitable for interior decoration and remain fresh for many days. They comprise the largest family (Orchidaceae) of flowering plants with 25,000 to 35,000 species belonging to $600-800$ genera (Chowdhery, 2001). 
At present cultivation of Orchids, is gaining momentum in India. It has got an excellent market potential in the floriculture industry. Despite the fact that India has diversified climate, low cost of labour and progressive farming technology, the Orchid industry is still in an infant stage for commercial cultivation. This has been mainly due to nonavailability of planting material for large scale cultivation, lack of technology for commercial multiplication, lack of adequate techniques on production practices resulting in poor yield and quality, lack of post harvest handling technology for cut flower export and lack of incentives. Hence, selection of suitable media for good vegetative growth and flower yield of Orchids is very important.

The materials used as growing media for epiphytic orchids are entirely different from that used for other plants. Orchid growers use different media which are often expensive and difficult to obtain. However, it is quite important to find out cheap and suitable growing media from the materials available locally, in order to bring down the cost of cultivation.

Usually, epiphytes can be found clustered together at the top of the trees, where there is plenty of air and light. Here, the only source of moisture is rainfall and dews. They have thick leaves and pseudobulbs which are specialised in storing water. The epiphytic orchids have fleshy roots that are covered with a white coating called velamen. These roots can rot easily, if the medium is not allowed to dry out between waterings.

Gravel was suggested as the best media for producing quality flowers by Bateman (1957), who compared it with osmunda and bark and recorded more flowers per plant grown in gravel culture. Cibes et al., (1957) observed linear increase in plant height, length of flower stalk and number of florets per spike, when grown in gravel culture. Bose and
Bhattacharjee (1972) suggested large pieces of charcoal as an excellent growing medium for Cattleya, Epidendrum, Phalaenopsis, Dendrobium, Rhynchostylis and Vanda. Arora et al., (1978) suggested the same medium for Dendrobium. Studies of Poole and Sheehan (1977) indicated that both terrestrial and epiphytic orchids could be grown in a mixture of peat and perlite $(1: 1)$ with excellent results and also seen that Aerides multiflorum was found to perform well in a substrate of hardwood charcoal.

Singh (1978) proposed brick pieces and shredded tree fern fibre in 6: 1 ratio for growing Dendrobium, Aerides and Vanda. Bose and Bhattacharjee (1980) Dry coconut husks are used for commercial propagation of Dendrobium hybrid Pompadour by cuttings. These husks hold moisture and supply food to the growing plants and found to be very suitable for growing ornamental plants and monopodial orchids like Phalaenopsis and Vanda.

According to Bhattacharjee and Mukherjee (1981), growing media differ with types of orchids and the climate in which they are grown. Under tropical climate, where there is no danger of chilling of the roots in winter, free circulation of air around the roots would facilitate absorption of atmospheric moisture and thus, loose packing with more open compost in the pot is more beneficial. In temperate regions, tight packing with more fibrous compost is preferred to avoid chilling of root system.Various by-products from coconut industry such as coconut husk and fibre, were used as media for growing orchids. Coconut husk was cut into small pieces, washed thoroughly, dried in the sun and stored for preparing orchid compost (Abraham and Vatsala, 1981).

Orchids could also be grown successfully in inert potting materials such as silica gravel. The advantage of using these inert potting 
materials is that they do not decay and remain porous and intact indefinitely providing better aeration for roots (Stephen, 1981). Bhattacharjee (1981) obtained good growth and flowering in Dendrobium moschatum, when it was grown in blocks of hardwood charcoal and properly fertilized with nitrogen, phosphorus and potassium.

Studies on the performance of Dendrobium moschatum, a sympodial epiphytic orchid by Bhattacharjee and Mukherjee (1981) revealed that there was a marked improvement on growth and flowering of the orchid when it was grown on tree fern fibre whereas Aerides multiflorum a monopodial epiphytic orchid performed best in a substrate of hard wood charcoal. In another experiment conducted by Bhattacharjee (1982), he reported that Rhynchostylis performed with best growth and flowering in the substrate containing charcoal and tree fern fibre or charcoal, brick pieces and tree fern fibre. Charcoal has been accepted as an excellent potting media for Vandas and Cattleya (Boyd, 1983). Boyd (1983) stated that charcoal was an excellent potting media for Vanda and Cattleya. On the other hand, Nash (1983) suggested that Cattleya could be best grown in hardwood bark media. Similarly, experiments conducted by Bhattacharjee (1984) revealed that Cattleya showed a maximum stimulation of spike length, maximum number of florets per spike and longevity of flower spike when it was potted in the medium containing hardwood charcoal.

Henderson (1984) reported about different compost mixes for orchids, among which the best one was a mixture of charcoal, peat and styrofoam that provided a long lasting medium for all genera of Orchids. Bhattacharajee (1985) suggested that a vigorous and healthy root system in epiphytic orchids was the first step towards ensuring maximum growth and favourable nutrient supply. Hence, selection of ideal rooting media provides a high degree of success for profuse root growth. The materials used as potting media for epiphytic orchids were entirely different from those used for other plants because of their peculiar habitate. He tried 12 different potting substrates among which, chunks of hardwood charcoal as potting medium proved its superiority over the other media for all vegetative and flower characters. Charcoal absorbs gases that tend to rot the roots.

In a survey conducted by White (1986) on potting media used by orchid growers, an array of materials were listed. The materials included were fir bark, tree fern, osmunda fibre, coconut fibre, sphagnum moss, gravel or stones, charcoal, perlite and commercial orchid mixtures containing sugarcane waste, charcoal and perlite. A combination of different components was also tried by different orchid growers. According to Talukdar and Barooah (1987), Dendrobium densiflorum performed best in a combination of saw dust, charcoal, brick pieces and moss, by showing superiority for number of flowers per spike and blooming period, compared to the other five media tried. According to Grove (1988), Vanda and Ascocenda could be grown in excellent condition in plastic pots with lot of drainage holes or slatted wood baskets in a medium of chunks of hardwood charcoal.

Studies performed by Paul and Rajeevan (1992) on the influence of potting media on growth of Dendrobium revealed that a combination of charcoal, gravel, brick and coconut husk gave the maximum results in terms of percentage of plant survival and vegetative growth parameters such as plant height, number of leaves and leaf area. On the other hand, Kumar (1992) stated that Dendrobium hybrids potted in charcoal medium followed by fern roots and rubber 
seed husks gave the best results with regard to plant height, leaf area, length of floret stalk and number of florets per spike. Dematte (1996) observed the suitability of various potting media for cultivation of epiphytic orchids and concluded that the best potting media had been the pressed coconut bark alone or mixed with charcoal. Similarly, Hersh (1997) observed that potting media containing charcoal followed by fern roots promoted good plant growth, increased number of leaves and promoted early flowering in Dendrobium Orchids.

Saravanan (2001) Among different growing media tested coconut dust was found to be the best for plant height $(37.17 \mathrm{~cm})$, leaf area $(54.88 \mathrm{~cm})$ at $18 \mathrm{MAP}$, number of roots per plant (31.55), root length $(60.43 \mathrm{~cm})$ and early flower bud appearance (467 days), number of spikes per plant (2.60), spike length $(44.56 \mathrm{~cm})$. The treatment (tile bits) recorded the highest number of leaves per plant (12.67) and number of spikes per plant (2.57), floret size $(7.40 \times 7.25 \mathrm{~cm})$ in Dendrobium hybrid Sonia 17. Arumugam and Jawaharlal (2004) revealed that coconut fiber as a growing media increases, number of shoots/plant, early flowering, spike length and number of florets/spike followed by tile bits in Dendrobium orchid cv. Sonia-17. Mani and Nagaraju (2005) studied the effect of different substrates on establishment and growth of tissue culture regenerated plants of Cymbidium hybrids and noted that the plantlets grown in cocopeat resulted in maximum increase in shoot length $(15.02 \%)$ with broad leaves, whereas the plantlets grown in cocopeat along with sand resulted in maximum increase in leaf number $(42.31 \%)$ and leaf length (32.24\%). Saravanan and Amit (2009) conducted an experiment on effect of different growing media and plant growth regulators on Dendrobium hybrid "Sonia-17". Application of BA @ 500 ppm+ Gravel+ Groundnut shell+ Cowdung resulted in earlier flower bud initiation at 73 DAT and maximum no. of spikes/ plant (2.20). The best growing media for Dendrobium were found (Gravel+ Groundnut shell+ Cowdung) and (Charcoal+ Cowdung+ Coconut fibre) for commercial cultivation of Orchids. Studies on effect of different potting media on plant growth and spike yield of Dendrobium Orchid was investigated by Neeteesh gupta et al., (2013) and reported that tile bits pieces found to be the best potting medium for growing Dedrobium orchids and produced the best vegetative growth and spike yield. Ahmad and Saravanan (2014) Opined that (NPK 10: 30: $30+0.3 \%$ Brick pieces + Gravel+ Poultry manure) was found to be statistically significant over other treatments which recorded highest plant height $(29.61 \mathrm{~cm})$, no. of leaves (9.69), leaf area $\left(36.11 \mathrm{~cm}^{2}\right)$, no. of new shoots per plant (4.58), shoot girth (3.16), root length $(16.73 \mathrm{~cm})$, no. of roots per plant (20.25), total no. of spikes per plant (3.47), no. of florets per spike (10.69) and longevity of spike (42.91 d) in Dendrobium Orchid cv. Sonia Hiskula. Srinivasulu et al., (2016) revealed that media comprising of Charcoal + Peanutshell + Maize rindpieces recorded maximum plant height $(38.57 \mathrm{~cm})$, no. of leaves (10.33), no. of pseudo bulbs (5.33), stalk length $(39.69 \mathrm{~cm})$ and no. of florets per spike (8.20) in Dendrobium var. Sonia 17.

From the present study it can be concluded that, potting media combination of Coconut husk + Charcoal + Brick pieces was good for commercial cultivation of Orchids.

\section{References}

Abranam, A. and Vatsala, P. 1981. Introduction to orchids. Tropical Botanical Garden and Research Institute. Trivanarum, pp. 533.

Arora, Y. K, Jain S.K. and Mukherjee, A. 1978. Ornamental Dendrobiums of 
North East India. Indian Journal of Horticultural sciences. 22(1): 16-19.

Arumugam and Jawaharlal. 2004. Effect of Shade Levels and Growing Media on Growth and Yield of Dendrobium Orchid Cultivar Sonia-17. Journal of Ornamental Horticulture. 7(1):107-110.

Arumugam, T. and Jawaharlal, M. 2004. Effect of shade levels and growing media on growth and yield of Dendrobium orchid cultivar Sonia-17. Journal of Ornamental Horticulture. 7 (1): 107-110.

Bateman, R.B. 1957 Gravel culture of orchids. American Orchid Society. Bulletin. 26: 778-787.

Bhattacharjee, S K. 1981. Effect of fertilizers on Dendrobium masehatunt. Die Gartenbauwiss. 46: 178-181.

Bhattacharjee, S K. 1985. Cultural management in orchids: Influence of different potting substrates on growth and flowering. In: Chadha, K.L. and F. Singh (ed.) Progress in Orchid Research (Proceedings of National Symposium on orchids) IIHR, Bangalore, pp. 66-68.

Bhattacharjee, S. K. and Mukherjee,T.K. 1981. Effect of potting media on the growth and flowering of some epiphytic and terrestrial orchids. Haryana Journal of Horticultural sciences. 10(1/2): 5866.

Bhattacharjee, S.K 1984 Effect of potting media on growth and flowering of Cattleya howringrane Veitch. My Forest. 20(4): 239-244.

Bhattacharjee, S.K. 1982. Influence of different potting substrates in growth and flowering of Rhynchostylis gigantea. Lal Baugh Journal. 27(1): 1114.

Bose, T.K. and Bhattacharjee, S.K. 1972. Orchid growing in warm climate. Indian Horticulture. 17(2): 25-27.

Bose, T.K. and Bhattacharjee, S.K. 1980. Orchids of India, Naya Prakash,
Calcutta, India, pp 132.

Boyd, A. 1983. Charcoal as a potting medium. American Orchid Society Bulletin. 52(5): 492-493.

Chowdhery, H.J. 2001. Orchid diversity in north- east India. Journal of Orchid society in India.15:1-17.

Cibes, H.R, Cernuda, C. and Loustalot, A.J. 1957. New orchid medium lowers the production cost. American Orchid Society. Bulletin. 26: 409-411.

Dematte, B. 1996. Water studies on substrates of plant origin for cultivation of epiphytic orchids. Pesquisa agropecuaria. Brasileria. 31(11): 803813.

Grove, D.L. 1988 Growing strap-leaf Vandas. American Orchid Society Bulletin. 57(12): 1351-1359.

Gufran Ahmad and Saravanan,S. 2014. Effect of NPK and potting media on plant growth and spike yield of Dendrobium orchid cv. Sonia Hiskula. Hort Flora Research Spectrum, 3(4): 383-385.

Henderson, L. 1984. Orchid culture in United States. Proceedings of eleventh world orchid conference, Florida. pp 159-161.

Hersh, H. 1997. One big One small Orchids. 66(4): 376-377.

Kumar, P.K.S. 1992. Potting media and post transplantation growth of Dendrobium hybrid seedlings. Journal of Orchid Society of India. 6(1-2): 131-133.

Mani, S. K. and Nagaraju, V. 2005. Influence of potting media on acclimatization and growth of in vitro plantlets of Cymbidium hybrids. Journal of Ornamental Horticulture. 7 (1): 23-30.

Nash, N. 1983. Cattleya culture. American Orchid Society Bulletin. 52(5): 469-477.

Paul, C. and Rajeevan, P.K. 1992. Influence of media on growth parameter in Dendrobium. Journal of Orchid Society of India. 6(1-2): 125-130.

Poole, H.A and Sheehan, T. 1977. Effect of potting media on the growth of 
terrestrial and epiphytic orchids. American Orchid Society Bulletin. 46: 155-160.

Saravanan, S (2001) Studies on standardization of certain production technologies for Dendrobium orchid hybrid sonia-17.A thesis submitted to Tamilnadu agricultural university.

Saravanan, S. and Amit, K. 2009. Stardardization of Agro-Techniques of Dendrobium Orchids under protected condition. New agriculturist. 20(1,2): $141-45$.

Sarvanan, A. and Nambisan, K. M. P. 1995. Utilization of coir pith as pot culture medium for Begonia semperflorens. Madras Agriculture Journal. 82 (11): 587-589.

Singh, F. 1978. Orchid growing in Bangalore. Indian Horticulture. 22(4): 14-17.
Singh, F. 1978. Orchid growing in Bangalore. Indian Horticulture. 22(4): 14-17.

Srinivasulu, G.B, Harshavardhan, M. and Chandhan, K. 2017. Comparative effect of different potting media on vegetative and reproductive growth of Dendrobium Orchid cv. Sonia 17. Environment and Ecology. 35(2): 1252-1255.

Stephen, R.B. 1981 Orchid culture and Growing media. American Orchid Society Bulletin. 50(11): 1318-1324.

Talukdar, M. and Barooah, S. 1987. Effect of pot mixture on flowering of Dendrobium densiflorum. Acta Horticulturae. 205: 145-148.

White, J. 1986. Media Mania-Surveying the mixed up real of orchid potting materials American Orchid Society Bulletin. 55: 488-500.

\section{How to cite this article:}

Sanghamitra, M., J. Dilip Babu, B.V.K. Bhagavan and Salomi Suneetha, D.R. 2019. Role of Potting Media in the Cultivation of Orchids - A Review. Int.J.Curr.Microbiol.App.Sci. 8(01): 218-223. doi: https://doi.org/10.20546/ijcmas.2019.801.024 